\title{
THE IMPACT OF TWINNING AND STILLBIRTH ON REPRODUCTIVE AND ECONOMIC PERFORMANCE IN LARGE HUNGARIAN DAIRY HERDS
}

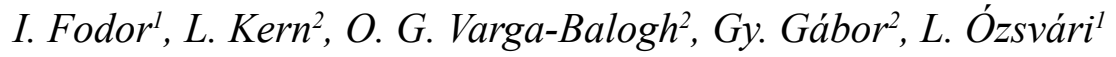 \\ fodor.istvan@univet.hu
}

${ }^{1}$ University of Veterinary Medicine,

Department of Veterinary Forensics, Law and Economics,

István út. 2, Budapest, 1078, Hungary

${ }^{2}$ Research Institute for Animal Breeding, Nutrition and Meat Science,

National Agricultural Research and Innovation Centre, Herceghalom,

Szent-Györgyi Albert út. 4, Gödöllö 2100, Hungary

The aim of our study was to quantify the effect of twinning and stillbirth on the main reproductive parameters, and to estimate the resulting economic loss on large-scale commercial dairy farms.

The data of 3.660 calvings that occurred on five large Hungarian Holstein-Friesian farms in 2016 and 2017 were analysed retrospectively. Information about twin calvings, stillbirths and uterine treatments were gathered. The main reproductive indices (i.e. calving to conception interval - CCI, services per conception$S P C$, and first service conception risk-CRI) were calculated based on cow-level data. Statistical analyses were performed by using linear and logistic regression, and Dunnett-test. The economic losses related to twinning and stillbirth were estimated by partial budget analysis (1 EUR $=320 \mathrm{HUF})$.

Overall, twinning and stillbirth occurred in $4.1 \%$ and $6.9 \%$ of the calving events. Twinning was more likely, whereas stillbirth was less likely in multiparous cows (odds ratio [OR]: 4.18 and 0.64, $P<0.0001$ and $P=0.0015$, respectively). Following twin calving, CCI and SPC were increased by 12.8 days and by 2.8 , respectively, whereas CRI was reduced by 7.1 percentage points. Twinning caused an estimated loss of 50.4 EUR/case. The analysed reproductive parameters were not impaired after stillbirth. Although, the reduction of calf number and the excess semen usage led to 112.5 EUR estimated loss per stillbirth case, on average.

Twinning and stillbirths are significant sources of economic loss on dairy farms, therefore, their prevalence should be reduced.

\section{Keywords: DAIRY CATTLE, REPRODUCTION, TWINNING, STILLBIRTH, ECONOMICS}

The events of the peripartal period require special attention in dairy cattle, since the majority of those animal health problems that may potentially reduce productive and economic performance occur during this period [7]. The prevalence of twin calving is approximately $10 \%$, on average, although it varies widely among dairy farms $[6,12]$. Twin pregnancies increase the risk of pregnancy loss, dystocia, stillbirth, calf mortality, and culling of the dam, moreover, gestation length and birth weight of the calves are reduced. Freemartinism occurs in $92-98 \%$ of those twin pregnancies, when calves from both sexes are born $[6,8,12]$.

Stillbirth is defined as the death of a calf just prior to, during, or within 24 to $48 \mathrm{~h}$ of parturition, following a normal gestation length [3, 10]. The prevalence of stillbirth ranges from 0.1 to $19.2 \%$, but on most farms it is between 6.5 and $9.3 \%[1,9,10]$. Stillbirth reduces milk produc- tion mainly during early lactation, and increases the risk of culling of the cow, as well $[2,5]$.

The aim of our study was to survey the occurrence of twinning and stillbirths, and to quantify their effects on the reproductive and economic performance on Hungarian dairy farms.

\section{Materials and methods}

The study was conducted in five large commercial Hungarian dairy herds. In each herd, the number of cows exceeded 390, treatments were regularly recorded in the farm management software (RISKA, Systo Kft., Budapest, Hungary), and shared the same reproductive advisor. Herd size, milk production and culling data of the studied herds are shown in table 1.

The protocol of reproductive examinations and treatments was identical on every studied 
Herd size, production and culling data

Table 1 of the surveyed herds (average of 2016 and 2017)

\begin{tabular}{|l|c|c|c|c|}
\hline Herd & $\begin{array}{c}\text { Number } \\
\text { of cows }\end{array}$ & $\begin{array}{c}305-\text { day } \\
\text { milk yield, } \\
\text { kg }\end{array}$ & $\begin{array}{c}\text { Number } \\
\text { of milkings } \\
\text { per day }\end{array}$ & $\begin{array}{c}\text { Annual } \\
\text { culling rate, } \\
\%\end{array}$ \\
\hline A & 420 & 8,776 & 2 & 30.5 \\
\hline B & 400 & 8,691 & 3 & 35.8 \\
\hline C & 547 & 10,349 & 3 & 31.4 \\
\hline D & 502 & 8,618 & 3 & 30.0 \\
\hline E & 396 & 8,720 & 2 & 33.7 \\
\hline
\end{tabular}

farm. Data were collected from the farm management software about the calvings that occurred in 2016-2017, as well as about the postpartum treatments and reproductive parameters. Those cows were considered affected with retained placenta, in which the fetal membranes were still present on the next day following calving. Uterine inflammation was diagnosed based on the evaluation of the discharge. The prevalence of twinning and stillbirth was quantified, furthermore, the main reproductive indices (calving to conception interval - CCI, first service conception risk - CR1, services per conception - SPC) were calculated, as well. The relationship of twinning and stillbirth with retained placenta, uterine inflammation, CCI, and CR1 were analysed. Statistical analyses were performed by using linear and logistic regression, and Dunnett-test. Data were analysed in $R$ version 3.4.2 ( $R$ Core Team, 2017).

In the partial budget model for the quantification of the economic losses caused by twinning and stillbirth, calf revenue, cost of open days and insemination cost were taken into account [11]. When calculating calf revenue, we assumed that calves are sold. According to Northern American studies, single and twin calvings yield 0.93 and 1.70 live calves, respectively, and twin calves weigh $15 \%$ less compared to single calves, on average [4]. Stillbirth reduces calf revenue, and the insemination cost of producing the stillborn calf is also incurred. Average prices and costs of the studied farms were used for the calculations; each extra open day was assumed to cost $2.5 \mathrm{EUR}$ $(1 \mathrm{EUR}=320 \mathrm{HUF})$. The economic analysis was performed in Microsoft Excel 2016.

\section{Results and discussion}

Altogether 3,660 calving events occurred in the studied period, of which $4.1 \%$ was twin calving and $6.9 \%$ was stillbirth (table 2). Twinning was more likely, whereas stillbirth was less likely in multiparous compared to primiparous cows.

The average CCI, CR1 and SPC were 139.8 days, $16.3 \%$ and 5.74 , respectively. The major reproductive parameters of the cows with twins or stillbirth by parity are shown in table 3 . Following twin calving, a remarkable, although, nonsignificant decline was observed in the reproductive parameters. Following stillbirth, no marked decline in the reproductive indices was found.

The reproductive performance following twinning and stillbirth was compared to those cows, which gave birth to a single, live calf, and were free from postpartum uterine diseases ("healthy" cows, table 4). Despite the remarkably poorer reproductive performance in cows after twin calving, these differences remained not significant $(\mathrm{P}>0.05)$. Fertility parameters declined after stillbirth, however, their differences compared to those of the "healthy" cows did not prove to be significant $(\mathrm{P}>0.05)$.

The decline of the reproductive performance following twinning is probably attributable to the disorders of the uterine involution. However, we could not observe the negative effect of twin calving on the performance of the primiparous cows, which is most probably related to the low prevalence of twinning at first calving. The reproductive parameters did not significantly decline following stillbirth. This may be explained by these cows being subject to uterine treatments, which

The occurrence of twinning and stillbirth by parity $(n=3,660)$

\begin{tabular}{|c|c|c|c|c|c|c|c|c|}
\hline & $\mathrm{n}$ & Prevalence, $\%$ & Parity & $\mathrm{n}$ & Prevalence by parity, $\%$ & $\mathrm{OR}^{\mathrm{a}}$ & $95 \% \mathrm{CI}^{\mathrm{b}}$ & $\mathrm{P}$ \\
\hline \multirow{2}{*}{ Twinning } & \multirow{2}{*}{149} & \multirow{2}{*}{4.1} & 1 & 16 & 1.3 & \multicolumn{2}{|c|}{ Reference } & \multirow{2}{*}{$<0.0001$} \\
\hline & & & $\geq 2$ & 133 & 5.5 & 4.18 & $2.5-7.45$ & \\
\hline \multirow{2}{*}{ Stillbirth } & \multirow{2}{*}{251} & \multirow{2}{*}{6.9} & 1 & 113 & 9.0 & \multicolumn{2}{|c|}{ Reference } & \multirow{2}{*}{0.0015} \\
\hline & & & $\geq 2$ & 138 & 5.7 & 0.64 & $0.48-0.84$ & \\
\hline
\end{tabular}

Note: ${ }^{\mathrm{a}}$ - odds ratio, ${ }^{\mathrm{b}}-95 \%$ confidence interval. 
The major reproductive parameters in case of twinning and stillbirth $(n=3,660)$

\begin{tabular}{|c|c|c|c|c|c|c|c|c|}
\hline Parity & Twinning/Stillbirth & $\mathrm{N}$ & $\mathrm{CCI}^{\mathrm{a}}$, days & Difference & $\mathrm{SPC}^{\mathrm{b}}$ & Difference & $\mathrm{CR} 1^{\mathrm{c}}, \%$ & Difference \\
\hline \multirow{2}{*}{ Primiparous } & Single calf & 1,233 & 141.6 & Reference & 5.3 & Reference & 18.6 & Reference \\
\hline & Twins & 16 & 124.8 & -16.7 & 4.2 & -1.1 & 9.1 & -9.5 \\
\hline \multirow{2}{*}{ Multiparous } & Single calf & 2,278 & 138.0 & Reference & 5.9 & Reference & 15.4 & Reference \\
\hline & Twins & 133 & 156.9 & 18.9 & 9.2 & 3.3 & 9.6 & -5.9 \\
\hline \multirow{2}{*}{ Altogether } & Single calf & 3,511 & 139.4 & Reference & 5.7 & Reference & 16.6 & Reference \\
\hline & Twins & 149 & 152.2 & 12.8 & 8.5 & 2.8 & 9.5 & -7.1 \\
\hline \multirow{2}{*}{ Primiparous } & Live calf & 1,136 & 141.9 & Reference & 5.1 & Reference & 19.1 & Reference \\
\hline & Stillbirth & 113 & 134.8 & -7.1 & 6.9 & 1.8 & 11.8 & -7.2 \\
\hline \multirow{2}{*}{ Multiparous } & Live calf & 2,273 & 139.4 & Reference & 6.1 & Reference & 14.9 & Reference \\
\hline & Stillbirth & 138 & 124.9 & -14.5 & 5.1 & -1.0 & 18.7 & 3.8 \\
\hline \multirow{2}{*}{ Altogether } & Live calf & 3,409 & 140.4 & Reference & 5.7 & Reference & 16.4 & Reference \\
\hline & Stillbirth & 251 & 129.7 & -10.7 & 6.0 & 0.3 & 15.4 & -1.0 \\
\hline
\end{tabular}

Note: in this and the next table ${ }^{\mathrm{a}}$ - calving to conception interval, ${ }^{\mathrm{b}}$ - services per conception, ${ }^{\mathrm{c}}$ - first service conception risk.

The major reproductive parameters of cows with twins and stillbirth compared to "healthy" cows

(i.e. cows that gave birth to one live calf and were free from postpartum uterine diseases) $(\mathbf{n}=\mathbf{3 , 6 6 0})$

\begin{tabular}{|l|c|c|c|c|c|c|c|}
\hline & $\mathrm{n}$ & $\mathrm{CCI}^{\mathrm{a}}$, days & Difference & SPC $^{\mathrm{b}}$ & Difference & $\mathrm{CR}^{\mathrm{c}}, \%$ & Difference \\
\hline "Healthy" & 2,008 & 130.4 & Reference & 4.9 & Reference & 18.7 & Reference \\
\hline Twinning & 149 & 152.2 & +21.8 & 8.5 & +3.6 & 9.5 & -9.2 \\
\hline Stillbirth & 251 & 129.7 & -0.7 & 6.0 & +1.1 & 15.4 & -3.3 \\
\hline
\end{tabular}

was often not performed in cows that gave birth to live calves, although fertility could also be negatively affected in these animals if a subclinical uterine disease was present.

The prevalence of retained placenta and uterine inflammation was 13.3 and $29.4 \%$, respectively. The risk of retained placenta was increased by twinning $(\mathrm{OR}=2.22, \mathrm{P}<0.0001)$ and stillbirth $(\mathrm{OR}=1.23, \mathrm{P}<0.0001)$, as well. The risk of uterine inflammation was not related to stillbirth $(\mathrm{OR}=1.05, \mathrm{P}=0.1364)$, although it was reduced after twinning $(\mathrm{OR}=0.76, \mathrm{P}<0.0001)$.

The results of the economic analysis are shown in table 5 . The number of extra calves could not compensate for the extra cost of open days and inseminations following twin calving.

Table 5

Economic analysis of twinning and stillbirth, EUR

\begin{tabular}{|l|c|c|}
\hline \multicolumn{1}{|c|}{ Cost factor } & Twin calving & Stillbirth \\
\hline Calf revenue & +25.3 & -64.2 \\
\hline Open days & -32.0 & +26.8 \\
\hline Insemination & -43.8 & -75.0 \\
\hline \multicolumn{1}{|c|}{ Altogether } & -50.4 & -112.5 \\
\hline
\end{tabular}

Note: Positive numbers indicate economic gains, negative numbers indicate economic losses.
The economic loss due to stillbirth exceeded the cost of twinning.

\section{Conclusions}

Based on our results, twinning was more common, whereas stillbirth was less common in multiparous compared to primiparous cows. Stillbirth caused larger losses than twinning, mainly due to the foregone calf revenue, and the cost of semen used to produce the stillborn calf. The risk of retained placenta was increased by twinning and stillbirth, as well. Both twinning and stillbirth should be considered significant sources of economic loss in large dairy herds.

Acknowledgements. The Project was supported by the European Union and co-financed by the European Social Fund: (1) EFOP-3.6.1-162016-00024 "Innovations for Intelligent Specialisation on the University of Veterinary Science and the Faculty of Agricultural and Food Sciences of the Széchenyi István University Cooperation"; (2) EFOP-3.6.2-16-2017-00012 "Development of a product chain model for functional, healthy and safe foods from farm to fork based on a the- 
matic research network"; and (3) EFOP-3.6.3VEKOP-16-2017-00005 "Strengthening the scientific replacement by supporting the academic workshops and programs of students, developing a mentoring process".

1. Atashi H., Zamiri M. J., Sayyadnejad M. B. Effect of twinning and stillbirth on the shape of lactation curve in Holstein dairy cows of Iran. Archives Animal breeding, 2012, vol. 55, issue 3, pp. 226-233. DOI: 10.5194/aab-55-226-2012.

2. Báder E., Kovács A., Szabó-Ari K., Bajcsy Á. C., Mádl I., Takács L., Szenci O. Incidence of stillbirth in a large-scale Holstein-Friesian dairy farm in Hungary. Magyar Állatorvosok Lapja, 2009, vol. 131, issue 3, pp. 131-136. (in Hungarian)

3. Bicalho R. C., Galvão K. N., Cheong S. H., Gilbert R. O., Warnick L. D., Guard C. L. Effect of stillbirths on dam survival and reproduction performance in Holstein dairy cows. Journal of Dairy Science, 2007, vol. 90, issue 6, pp. 2797-2803. DOI: 10.3168/jds.2006-504.

4. Del Río S. N., Stewart S., Rapnicki P., Chang Y. M., Fricke P. M. An observational analysis of twin births, calf sex ratio, and calf mortality in Holstein dairy cattle. Journal of Dairy Science, 2007, vol. 90, issue 3, pp. 1255-1264. DOI: 10.3168/jds.S0022-0302(07)71614-4.

5. Fodor I., Búza L., Ózsvári L. Reproductive management and major fertility parameters of cows in large-scale Hungarian dairy herds. Magyar Állatorvosok Lapja, 2016, vol. 138, issue 11, pp. 653-662. (in Hungarian)
6. Gáspárdy A., Sheridan J., Ari M., Gulyás L. Twin calving and its connection to other economically important traits in dairy cattle. In: Abubakar M. (szerk.). Ruminants - The Husbandry, Economic and Health Aspects. InTech, Rijeka, 2018, pp. 61-82. DOI: 10.5772/intechopen.72905.

7. Hejel P., Csorba Cs., Gubik Z., Jónás S., Könyves L. Frequent nutritional-, herd-health- and management risk factors in transition period for dairy cows. Magyar Állatorvosok Lapja, 2016, vol. 138, issue 7, pp. 391-400. (in Hungarian)

8. Hossein-Zadeh N. G. Effects of main reproductive and health problems on the performance of dairy cows: A review. Spanish Journal of Agricultural Research, 2013, vol. 11, issue 3, pp. 718-735. DOI: $10.5424 /$ sjar/2013113-4140.

9. Mee J. Explaining unexplained bovine stillbirth: How to deal with farm blindness. The Veterinary Journal, 2013, vol. 197, issue 2, pp. 120-121. DOI: $10.1016 /$ j.tvj1.2013.05.004.

10. Mee J. F., Sánchez-Miguel C., Doherty M. Influence of modifiable risk factors on the incidence of stillbirth / perinatal mortality in dairy cattle. The Veterinary Journal, 2014, vol. 199, issue 1, pp. 1923. DOI: $10.1016 / j$.tvj1.2013.08.004.

11. Ózsvári L., Kerényi J. Quantification of losses due to reproductive disorders on a large-scale HolsteinFriesian dairy farm. Magyar Állatorvosok Lapja, 2004, vol. 126, no. 9, pp. 523-531. (in Hungarian)

12. Spitzner A., Németh T., Egerszegi I., Balogh O., Kern L., Gábor Gy. Occurrence of twin pregnancy and calving and its effect on reproduction in ruminants. Magyar Állatorvosok Lapja, 2013, vol. 135, issue 10, pp. 595-608. (in Hungarian) 